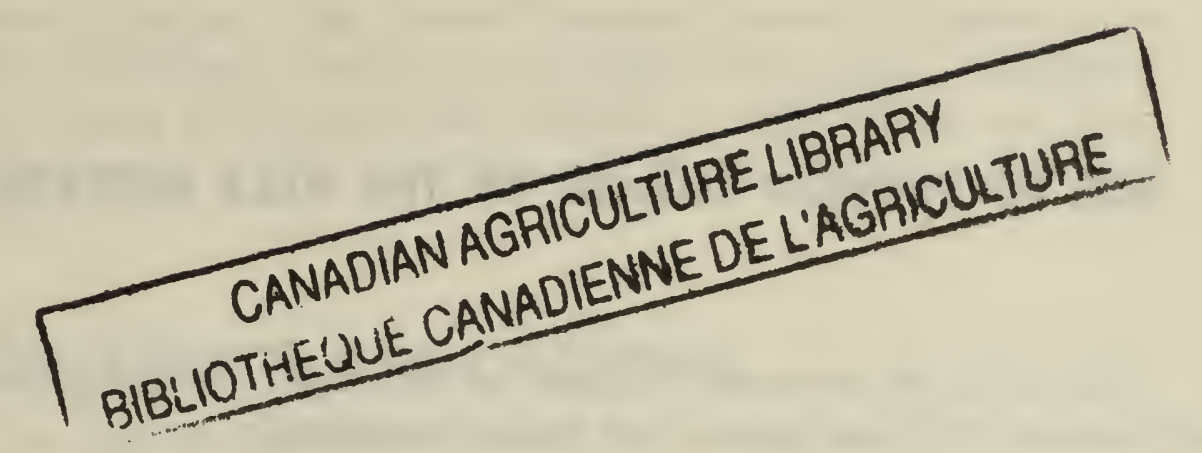

Control of the

PALE WESTERN GUTMORM 


\section{HOW TO PREVENT DAMAGE BY THE PALE WESTERN CUTWORM}

Watch for the cutworm forecast on this insect in the press or in broadcasts each year in July and make your plans accordingly.

Prevent infestations by not cultivating or allowing livestock on summerfallow fields between August 1 and September 15 (page 4).

If an outbreak is forecast for your district, do not seed stubble fields unless you starve the young cutworms (page 5) or unless you are prepared to use insecticide sprays if damage occurs (page 5).

Watch all seeded fields early in the spring for damage by the cutworm. If they are infested, spray at once with one of the recommended insecticides (page 5).

If the cutworms destroy a field, do not re-seed it before June 20 unless you spray it first with an insecticide (page 5 ). 


\title{
CONTROL OF THE PALE WESTERN CUTWORM
}

\author{
L. A. Jacobson \\ Research Station, Lethbridge, Alta., and \\ H. McDonald \\ Research Station, Saskatoon, Sask.
}

The pale western cutworm ${ }^{1}$ has caused serious losses to grain crops throughout the prairies of Western Canada at intervals since 1911. Outbreaks occur after one or more years of below-normal rainfall in April, May, and June. You can prevent infestations by cultural methods and destroy larvae in damaged fields with insecticides.

\section{RELATION TO OTHER CUTWORMS}

The pale western cutworm (Figures 1 to 3 ) is one of several cutworms that attack crops in the Prairie Provinces. Although it is usually a pest of the prairies, it is sometimes found in parkland areas, where it may occur along with the red-backed cutworm ${ }^{2}$. Another species, the army cutworm ${ }^{3}$, often damages various crops in southern Alberta and southwestern Saskatchewan.

The pale western cutworm is uniformly pale gray with a light-yellowish head; the front of the head has two distinct, short, black marks forming the letter H. The red-backed cutworm is moderately dark gray on the upper half of its body and has two broad, dull-red stripes along its back. The army cutworm varies from gray to greenish black and has two thin, cream-colored stripes.

\section{LIFE HISTORY}

The pale western cutworm is the larva of a moth, or 'miller', that usually flies from about August 10 to September 15. The moths lay their eggs in loose, dusty soil. The eggs normally remain unhatched in the ground until spring. They hatch whenever the soil is moist, soon after the frost leaves the ground.
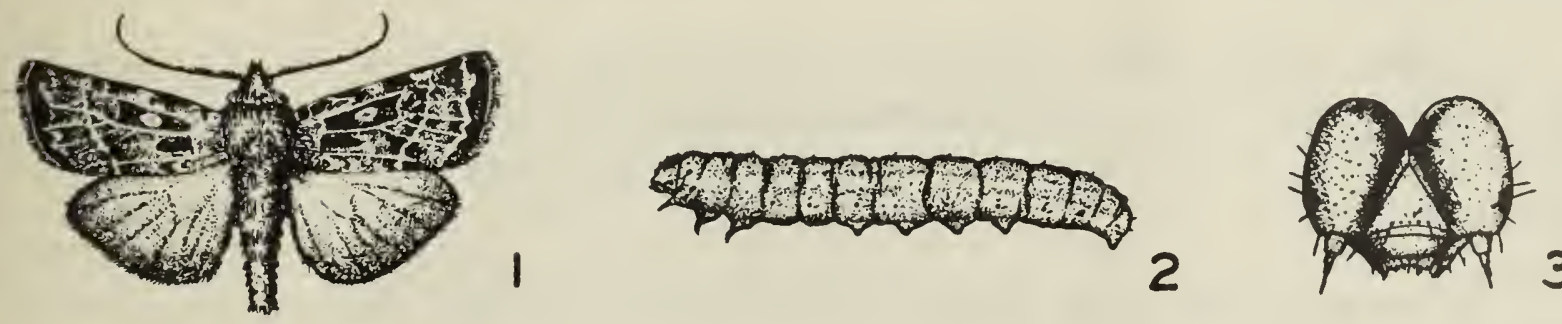

Figures 1-3. The pale western cutworm.

1, Moth. 2, Full-grown larva. 3, Head of larva.

\footnotetext{
$1_{\text {Agrotis orthogonia Morr. }}$

${ }^{2}$ Euxoa ochrogaster (Guen.).

${ }^{3}$ Chorizagrotis auxiliaris (Grote).
} 
The newly hatched larvae are very small, about $1 / 8$ inch long, and almost colorless. They can live in the soil for several weeks without food. They begin to feed when vegetation shows above the soil surface and continue feeding until about the third week of June. They usually feed below ground. The first signs of feeding are holes and notches in the leaves. Later grain, volunteer growth, and weeds are cut off at or below the ground level.

When full-grown the larvae (Figure 2) are about $1 \frac{1}{2}$ inches long. Then they cease feeding, form earthen cells in the ground, enter a resting stage, and later change to dark-brown pupae. The moths emerge from these about mid-August and fly about in search of food and suitable soil for egg-laying until about September 15.

\section{CONTROL MEASURES}

A forecast of infestation by this cutworm is prepared annually in July and publicized through the provincial departments of agriculture in Alberta and Saskatchewan by newspapers, radio, television, and other media. If you live in an area where the cutworms are expected, use one or all of the following control measures:-

\section{Do not work land hetween August 1 and September 15}

To prevent infestations, keep your fields unsuitable for egg-laying. The moths lay eggs only in loose, dusty soil and do not lay in fields in which the surface soil is even slightly crusted.

Complete all tillage to destroy weeds on summer fallow as late in July as possible. Do not cultivate fields or allow livestock on them during August and early September, when the eggs are laid. In this way the crust that is formed by light showers will remain unbroken.

In some years there is no rainfall to crust the soil until after the moths begin to lay their eggs. Also, in certain types of heavy soils the crust may break down after the soil becomes dry. Then your fields may be infested.

If there is any doubt about the crust while the moths are flying, examine your fields every few days in the following spring after the plants emerge for signs of feeding by the cutworms. See page 5 for treatment with chemicals if necessary.

To avoid breaking the crust on the soil, sow winter wheat or rye before August 1 or after September 15.

Teeds and wind erosion after heavy rains sometimes become a problem before mid-September. It may be necessary to choose between the loss of moisture from weeds, or serious wind erosion, and the possible loss from cutworms. 


\section{Starve young cutworms in the spring}

You can destroy the cutworms by starving them after they have started to feed and develop. This method is especially effective in stubble fields in areas where a severe outbreak is forecast.

To rid an infested field of the cutworms by starvation, delay the spring cultivation until weeds (except stinkweed) and volunteer grain are 1 or 2 inches high. Then cultivate the field thoroughly and destroy all growth. Do not sow grain until 10 days after completing the cultivation.

\section{Control cutworms with insecticides}

If you do not starve the cutworms, watch stubble crops closely after they emerge for cutworms and signs of feeding. You can kill the cutworms and prevent further loss by spraying infested fields with an insecticide as soon as damage appears (See page 6 for fields likely to be infested).

Use any of the following insecticides and rates: endrin, 4 ounces of the active ingredient per acre; dieldrin, 6 ounces; chlordane, 24 ounces. These are all available as emulsible concentrates. Apply the spray with a standard field sprayer at 6 or 7 gallons per acre.

Poisoned baits are not effective.

\section{Cautions}

Follow closely all the cautions listed on the insecticide label, especially those concerning grazing and harvesting for forage.

\section{RE-SEEDING DAMAGED FIELDS}

Do not re-seed fields until the cutworms have been killed or have ceased feeding. They cease feeding when they are about $1 \frac{1}{2}$ inches long, usually about June 20. If you have applied one of the recommended chemicals, wait only two or three days before re-seeding.

\section{FURTHER INFORMATION}

For information on areas where damage is expected, consult your agricultural representative or district agriculturist or write to the research station of the Canada Department of Agriculture at Lethbridge, Saskatoon (University Sub Post Office), or Winnipeg (Box 6200, Winnipeg 1). 


\section{FIELDS LIKELY TO BE INFESTED IN OUTBREAK AREAS}

1. Fields that were cropped the year before and harvested, worked, or pastured while the moths were flying (August 10-September 15).

2. Summer-fallowed fields that were disturbed while the moths were flying or that later received drift soil from infested fields.

3. Fields sown or pastured while the moths were flying.

\section{FIELDS NOT LIKELY TO BE INFESTED IN OUTBREAK AREAS}

1. Summer-fallowed fields that were not disturbed while the moths were flying (August 10-September 15) and that did not receive any drift soil from infested fields.

2. Other fields that were not disturbed while the moths were flying. 


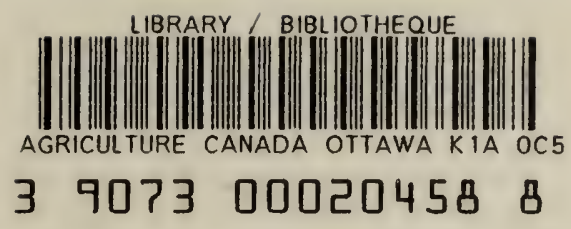


Revision of Processed Publication Series, Entomology, No. 62, 1949.

Copies of this publication may be obtained from

Information Division

CANADA DEPARTMENT OF AGRICULTURE

Ottawa 